\title{
WestVirginiaUniversity
}

THE RESEARCH REPOSITORY @ WVU

West Virginia Agricultural and Forestry Experiment

Davis College of Agriculture, Natural Resources

Station Bulletins

And Design

$1-1-1979$

\section{Factors affecting rural land values in Greenbrier County, West Virginia}

Luis E. Maldonado

Dale Colyer

Follow this and additional works at: https://researchrepository.wvu.edu/ wv_agricultural_and_forestry_experiment_station_bulletins

\section{Digital Commons Citation}

Maldonado, Luis E. and Colyer, Dale, "Factors affecting rural land values in Greenbrier County, West Virginia" (1979). West Virginia Agricultural and Forestry Experiment Station Bulletins. 668.

https://researchrepository.wvu.edu/wv_agricultural_and_forestry_experiment_station_bulletins/566 @ WVU. It has been accepted for inclusion in West Virginia Agricultural and Forestry Experiment Station Bulletins by an authorized administrator of

The Research Repository@WVU. For more information, please contact ian.harmon@mail.wvu.edu. 
[Blank Page in Original Bulletin] 


\section{Contents}

Introduction $\ldots \ldots \ldots \ldots \ldots \ldots \ldots \ldots \ldots \ldots \ldots \ldots \ldots \ldots \ldots$

Procedures ........................... 1

The Sampling Procedure ..................

Regression Model ....................... 2

The Study Area $\ldots \ldots \ldots \ldots \ldots \ldots \ldots \ldots \ldots \ldots \ldots, 5$

General Land Use Characteristics .............. 5

Agricultural Characteristics ................... 5

Land Transfers in Greenbrier County ............... 6

Characteristics of the Land Market ................ 17

Buyers and Sellers of Land .................. 17

Reasons for Selling and Buying Land ............ 17

Consideration and Acreage ................... 20

Land Use at Time of Sale ..................... 20

Financing of Land Purchases................. 20

The Regression Model ........................... 21

The Sellers' Model ........................... 25

The Buyers' Model............................. 25

Regression Results $\ldots \ldots \ldots \ldots \ldots \ldots \ldots \ldots \ldots \ldots, 26$

Sellers' Model ......................... 26

Buyers' Model ......................... 27

Conclusions ................................ 30 


\section{List of Tables}

Table 1. SCS Inventory and Non-Inventory Acreages in West Virginia and Greenbrier County - 1958-1967

Table 2. Number of Farms, Acreages and Values in West Virginia and Greenbrier County - 1954-1974

Table 3. Number of Farms by Size in West Virginia and Greenbrier Coun. ty - 1954-1974

Table 4. Selected Land Transfers in Greenbrier County - 1970-1975

Table 5. Selected Land Transfers and Values in Greenbrier County by Year - 1970-1975

Table 6. Average Per Acre Prices for Selected Land Transfers in Green. brier County by Years, 1970-1975, in Constant 1972 Dollars

Table 7. Selected Land Transfers and Values in Greenbrier County by Per Acre Price - 1970-1975

Table 8. Selected Land Transfers and Values for Greenbrier County by Acreage - 1970-1975

Table 9. Selected Land Transfers in Greenbrier County by Rights Transferred - 1970-1975

Table 10. Personal Characteristics of Sellers and Buyers of Rural Land in Greenbrier County, West Virginia - 1970-1975

Table 11. Sources of Income of Sellers and Buyers of Rural Land in Greenbrier County, West Virginia - 1970-1975

Table 12. Sellers' Main Reasons for Selling Land in Greenbrier County, West Virginia - 1970-1975

Table 13. Types of Buyers and Their Reasons for Buying Rural Land in Greenbrier County

Table 14. Consideration and Acreage for the Sample of Rural Land Sales in Greenbrier County, West Virginia - 1970-1975

Table 15. Land Use on an Average Farm at the Time of Sale

Table 16. Financing of Land Purchases in Greenbrier County, West Virginia - 1970-1975

Table 17. Statistically Significant Partial Regression Coefficients in the Sellers' Model

Table 18. Statistically Significant Partial Regression Coefficients in the Buyers' Model 


\title{
Factors Affecting Rural Land Values In Greenbrier County, West Virginia
}

\author{
Luis E. Maldonado and Dale Colyer
}

\section{INTRODUCTION}

Over the last decade land values in the United States have increased at a compound rate of 6.9 percent nationally. The strongest rates of change seem to have occurred in those areas where land use was changing sharply, while less rapid but strong increases occurred in more agriculturally oriented areas. During the same period land values in West Virginia have increased at a compound rate of 9.9 percent. Land prices in West Virginia increased in the decade by $\mathbf{4 3 . 5}$ percent more than for the United States.

This bulletin reports on a study conducted by the West Virginia University Agricultural and Forestry Experiment Station of rural land values in Greenbrier County for the years 1970-1975. The general objective was to develop information and knowledge about the organization, structure, and performance of the rural land market. Specific objectives were:

1. To describe the general land market situation in Greenbrier County.

2. To review agricultural land transfers from 1970 to 1975.

3. To analyze factors affecting values in the county.

\section{PROCEDURES}

The study was carried out by using rural land sales data for Greenbrier County for the period 1970-1975. Transfer data from courthouse records were used to isolate all land sales of ten or more acres that were made outside of the municipalities in the county. The transfer data did not identify agricultural land, thus all rural land sales were used. Transfers which were not bona fide sales and transfers between persons with the same surname were excluded from the analysis. There were 718 acceptable transfers during the six-year period, with 60 transfers in 1970, 133 in 1971, 159 in 1972, 146 in 1973, 120 in 1974, and 100 in 1975.

Data on all transfers were used to review general trends and features of the land market transfers in Greenbrier County from 1970 to 1975. Sample data were used in a statistical model to help explain differences in the per acre price of agricultural lands.

\section{The Sampling Procedure}

After collection of the primary transfer data, the sample of sales for which the buyer and seller would be interviewed was drawn. Land transfers for the 1970-1975 period were divided into ten strata based on per acre prices. In each stratum the names of buyers and sellers of land who made up the sample were determined, assigned numbers, and a table of random numbers used to draw the sample. 
A sample of 232 names of pairs of sellers and buyers of land was drawn. These were to be interviewed but because of problems such as absenteeisms, addresses unknown, and unwillingness to answer the ques. tionnaire, only 102 paired observations from willing sellers and buyers of land were collected.

\section{Regression Model}

A multiple linear regression was used to analyze factors affecting land values. The per acre price of the rural land in Greenbrier County, West Virginia, was hypothesized to be a function of the following variables:

\section{A - Property characteristics variables}

A1 - Size and value variables

1 = acreage of the property

2 = total value of the property

$3=$ per acre value of the improvements

A2 - Location variables

4 = total mileage to town

$5=$ miles on dirt road

$6=$ miles on slag road

$7=$ miles on one-lane paved road

$8=$ miles on two-lane paved road

$9=$ miles on four-lane paved road

A3 - Present use variables

$$
\begin{aligned}
& 10=\text { acres of cropland } \\
& 11=\text { acres of pasture } \\
& 12=\text { acres of forest or woodland } \\
& 13=\text { acres of other land (idle, services and wasteland) }
\end{aligned}
$$

A4 - Best use variables

$$
\begin{aligned}
& 14=\text { acres of tillable land } \\
& 15=\text { acres of pastureland } \\
& 16=\text { acres of timberland } \\
& 17=\text { acres of wasteland }
\end{aligned}
$$

A5 - Water supply variables (dummy variable)

$$
\begin{aligned}
& 18=\text { water supply from a spring } \\
& 19=\text { water supply from a pond } \\
& 20=\text { water supply from a river } \\
& 21=\text { water supply from a well } \\
& 22=\text { water supply from the public service district } \\
& 23=\text { water supply from a cistern }
\end{aligned}
$$


A6 - Rights owned variables (dummy variable)

24 = surface rights

$25=$ fee simple rights

3 - Buyer's and seller's socioeconomic characteristics variables

B1 - Buyer's personal characteristics

26 = buyer's age

27 = buyer's education

28 = buyer's income

B2 - Buyer's occupational characteristics before the sale (dummy variables)

$29=$ farm work

$30=$ professional

$31=$ administrative

$32=$ sales or clerical

33 = laborer

$34=$ retired

$35=$ other

B3 - Buyer's occupational and residential characteristics after the sale (dummy variable)

$36=$ buyer farm or non-farm resident

$37=$ farm work

$38=$ professional

$39=$ administrative

$40=$ sales or clerical

$41=$ laborer

$42=$ retired

$43=$ other

B4 - Seller's personal characteristics

$44=$ seller's age

$45=$ seller's education

46 = seller's income 
B5 - Seller's occupational and residential characteristics before the sale (dummy variables)

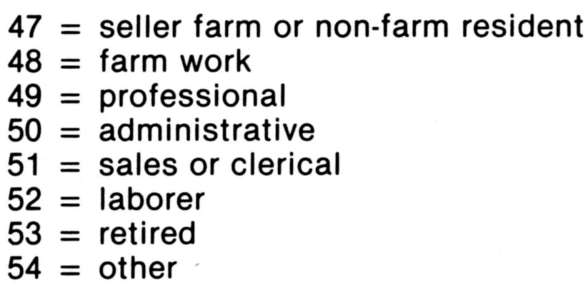

B6 - Seller's occupational characteristics after the sale (dummy variable)
$55=$ farm work
56 = professional
$57=$ administrative
$58=$ sales or clerical
59 = laborer
$60=$ retired
$61=$ other

C - Sale characteristics variables

C1 - Financial characteristics variables

62 = percentage of sale price financed by buyer's funds

$63=$ percentage of the sale price financed with credit

$64=$ rate of interest of the loan

C2 - Seller's subjective type variables - reasons to sell the land (dummy variables)
$65=$ money used
$66=$ right price to sell
$67=$ farming bad business
68 = seller's age

C3 - Buyer's subjective type variables - reasons to buy the land (dummy variables)

$69=$ for farming income

$70=$ for rental income

$71=$ for second home

$72=$ for future sale 


\section{THE STUDY AREA}

Greenbrier is the second largest county in West Virginia $(1,002.8$ square miles). It was created in 1778 and named for the principal river that drains the county. It is located in the southeastern part of the State. The county seat is the city of Lewisburg.

Greenbrier is a rural county with only one third of its population living in places of 1,000 to 2,500 population and the other two thirds in rural areas. Total population was 32,000 in 1970 . In 1960 it was 34,446 , a 6.8 percent reduction during that decade.

There are 787 miles of improved secondary and 131 miles of primary roads in the county. There are some small mining communities in the western section of the county. The central part is where agriculture is more important, while the north and east portions of the county are covered by forests. Wood production and recreation are important activities in those areas.

\section{General Land Use Characteristics}

Land use by major categories for Greenbrier County and West Virginia are shown in Table 1. The data were taken from West Virginia Soil and Conservation Needs Inventory. These are based on surveys in 1958 and 1967 and on the Census of Agriculture. Cropland and pastureland acreages declined during that period in both West Virginia and Greenbrier County, but the reduction of cropland was relatively larger in Greenbrier County. The shrinkage in the pastureland acreage on the other hand was relatively greater for the state, a 28 percent decline compared to only an 11 percent decline in Greenbrier County. Forest-land acreages seem to have increased at similar rates in both the State and county.

Of the total inventory acreage in Greenbrier County about two thirds is used for forests, one fifth for pasture, and one tenth for cropland. Nevertheless, Greenbrier County is an important farming area where beef, milk and broilers are produced. Hay, wheat, corn, and oats are important crops which are used mainly for feeding livestock.

\section{Agricultural Characteristics}

From Table 2 it can be seen that the number of farms was drastically reduced between the agricultural censuses taken in 1954 and 1974. Similarly, land in farms declined, but not by as much as the numbers of farms, with a result in increase in the average farm size. The proportion of the total land in Greenbrier County belonging to farms has decreased to roughly 70 percent, while the number of farms in 1974 represented only 37 percent of the number in 1954. The average size of farm in Greenbrier County has been consistently larger during the last four censuses than for the State.

The average per farm value of land and buildings in Greenbrier County rose from $\$ 9,910$ in 1954 to $\$ 80,368$ in 1974 . Much of this increment can be attributed to the increase in size of farms. However, average per acre values of land and buildings increased by 508 percent in that period. Average per acre values of land and building are approximately 20 percent higher in Greenbrier County than in West Virginia taken as a whole.

Data in Table 3 show the distribution of farms by size. Small farms are disappearing faster than big farms. The number of large farms of 500 acres and up is fairly stable in West Virginia, and in Greenbrier County their numbers have even increased. 


\section{LAND TRANSFERS IN GREENBRIER COUNTY}

Data on sales of land, the subject of this study, are contained in Tables 4 through 8 . There were 718 sales of land (in plots of ten or more acres) in Greenbrier County from 1970 to 1975 that met the other criteria used for this study. The amount of land that changed ownership was 75,393 acres, total sales value of $\$ 14,384,835$. The largest parcel transferred was 5,473 acres, which sold for $\$ 684,126$. The average land sale in this study was 105 acres and the average sale price was $\$ 20,035$. The average per acre price was $\$ 190.80$, with a range from a minimum of $\$ 2.48$ to a maximum of $\$ 7,060$ per acre.

The transfers and values per acre by year for the 1970-1975 period are shown in Table 5 . This clearly shows that land became gradually more ex. pensive during those six years. By making 1970 per acre prices equal to 100 and computing an index, it can be seen that an increase of more than two and a half times the 1970 levels had occurred by 1975.

By deflating the current prices with the GNP price deflator it was found that a "real" increase of about 150 percent occurred in the average price of land in Greenbrier County during the period 1970 to 1975 (Table 6). This, when compared with the data in Table 5, indicates that prices of land increased about 145 percent more than the general level of prices, i.e., 145 percent more than the amount of increase in all other prices.

Data in Table 7 shows land transfers classified by value categories and indicates that the majority of the land transferred in the county had a per acre price of less than $\$ 500$. A considerable number of the transfers had per acre prices of less than $\$ 100$. In general, these were the larger properties in acreages. This can be seen in the last column of Table 7, where per acre price clearly has an inverse relationship with average acreage.

Table 8 shows the land transfers and values in relation to acreage categories. This acreage categorization also clearly shows the inverse relationship between size of parcel and average price per acre, although the relationship did not hold for all size categories. The five transfers of more than 1,000 acres accounted for nearly one sixth of the land area transferred but for less than one twelfth of the value of all the land exchanged.

In Table 9 the transfers are divided according to the amounts of rights transferred. * This shows that of 718 transfers in Greenbrier County from 1970-1975, 670 were made in fee simple, 46 were for surface rights only, and on two the rights were not indicated by the transfer records. The average per acre price and average consideration were higher for the fee simple transfers than for the other two categories. The average acreage transferred in fee simple on the other hand was considerably less than the transfers of surface only. The forty-six transfers of land on which the mineral rights were excluded from the sale had lower per acre values.

\footnotetext{
*A brief digression is needed to explain this. "Property involves several distinct interests or rights which can be held separately and which when taken together represent a bundle of rights. The largest bundle of rights a private owner can hold in landed property in our society is known as complete ownership in fee simple" (Barlowe, p. 339). This bundle of rights can be separated and some can be sold or held separately. Mineral rights are frequently sold and/or held separately from the surface rights in West Virginia as well as in other states where coal, oil, gas, or other mineral rights deposits exist.
} 


\section{Table 1}

SCS Inventory and Non-Inventory Acreages in West Virginia and Greenbrier County — 1958 and 1967

\begin{tabular}{|c|c|c|c|c|}
\hline \multirow[b]{2}{*}{ Type of Land } & \multicolumn{4}{|c|}{ Acreages } \\
\hline & $\begin{array}{l}1958 \\
\text { State }\end{array}$ & County & $\begin{array}{l}1967 \\
\text { State }\end{array}$ & County \\
\hline Federal non cropland & 934,900 & 98,900 & 947,192 & 99,350 \\
\hline Urban and built-up & 433,200 & 9,500 & 486,419 & 9,542 \\
\hline Small water areas & 67,900 & 3,500 & 47,561 & 2,530 \\
\hline $\begin{array}{l}\text { Total non-inventory } \\
\text { acreage (a) }\end{array}$ & $1,436,000$ & 111,900 & $1,463,172$ & 111,422 \\
\hline Cropland & $1,521,100$ & 56,000 & $1,105,930$ & 32,455 \\
\hline Pasture & $2,572,400$ & 115,000 & $1,836,993$ & 102,527 \\
\hline Forest & $9,465,500$ & 365,200 & $10,429,867$ & 401,860 \\
\hline Other land & 415,000 & 8,600 & 565,818 & 8,216 \\
\hline $\begin{array}{l}\text { Total inventory } \\
\text { acreage (b) }\end{array}$ & $13,974,000$ & 544,800 & $13,938,608$ & 545,058 \\
\hline $\begin{array}{l}\text { Total land area } \\
\qquad(a+b)\end{array}$ & $15,410,000$ & 656,700 & $15,401,780$ & 656,480 \\
\hline
\end{tabular}

Source: Soil Conservation Service, West Virginia Soil and Water Conservation Needs Inventory, Morgantown, W.Va., 1970. 
Table 2

Number of Farms, Acreages and Values in West Virginia and Greenbrier County - 1954-1974

\begin{tabular}{|c|c|c|c|c|c|c|c|c|c|c|}
\hline \multirow{3}{*}{ 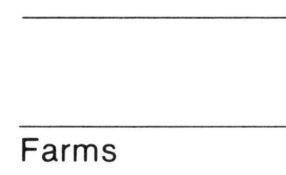 } & \multicolumn{2}{|c|}{1954} & \multicolumn{2}{|c|}{1959} & \multicolumn{2}{|c|}{1964} & \multicolumn{2}{|c|}{1969} & \multicolumn{2}{|c|}{1974} \\
\hline & State & County & State & County & State & County & State & County & State & County \\
\hline & & & & & & & & & & \\
\hline Number of farms & 68,583 & 2,172 & 44,011 & 1,529 & 34,504 & 1,237 & 23,142 & 862 & 19,123 & 814 \\
\hline $\begin{array}{l}\text { Proportion of } \\
\text { farms (percent) }\end{array}$ & 47.7 & 41.8 & 39.3 & 37.5 & 34.3 & 34.9 & 28.2 & 32.3 & 23.8 & 29.0 \\
\hline $\begin{array}{l}\text { Land in farms } \\
\text { (acres) }\end{array}$ & $7,351,874$ & 274,479 & $6,062,594$ & 245,980 & $5,278,592$ & 228,969 & $4,340,554$ & 212,016 & $3,662,300$ & 190,543 \\
\hline $\begin{array}{l}\text { Average size of } \\
\text { farm (acres) }\end{array}$ & 107.2 & 126.4 & 137.8 & 160.9 & 153 & 185.1 & 187.5 & 245.9 & 191.5 & 234.1 \\
\hline $\begin{array}{l}\text { Value of Land } \\
\text { and Buildings }\end{array}$ & & & & & & & & & & \\
\hline $\begin{array}{l}\text { Average per farm } \\
\text { (dollars) }\end{array}$ & 7,074 & 9,910 & 9,998 & 15,492 & 13,882 & 19,212 & 25,450 & 40,440 & 58,442 & 80,368 \\
\hline $\begin{array}{l}\text { Average per acre } \\
\text { (dollars) }\end{array}$ & 67.42 & 80.87 & 75.49 & 99.37 & 90.52 & 103.83 & 135.69 & 164.42 & 305 & 343 \\
\hline
\end{tabular}




State $^{1954}$ County State County State ${ }^{1959}$ County State County State County

Land in Farms

According to Use

Acres of cropland

Acres of woodland

$1,819,081$

$54,112 \quad 1,751,408$

$57,423 \quad 1,360,001$

$43,5651,553,500$

$58,006 \quad 1,358,864$

57,426

Acres of

pastureland

$$
2,553,003
$$

$125,739 \quad 1,955,316$

$118,112 \quad 1,923,989$

$124,184 \quad 1,124,205$

$78,774 \quad 877,835$

67,035

land

$\begin{array}{lllll}221,121 & 6,411 & 217,717 & 6,852 & 161,319\end{array}$

6,101

$\bullet$

"Land area of the State, 15,410,560 acres; the County, 656,640 acres.

* * Data merged with pastureland in the Censuses of 1969.

Source: U.S. Census of Agriculture, 1954, 1959, 1964, and 1969. 
Table 3

Number of Farms by Size in West Virginia and Greenbrier County - 1954-1974

\begin{tabular}{|c|c|c|c|c|c|c|c|c|c|c|}
\hline \multirow[b]{2}{*}{ Size in Acres } & \multicolumn{2}{|c|}{1954} & \multicolumn{2}{|c|}{1959} & \multicolumn{2}{|c|}{1964} & \multicolumn{2}{|c|}{1969} & \multicolumn{2}{|c|}{1974} \\
\hline & State & County & State & County & State & County & State & County & State & County \\
\hline All farms & 68,583 & 2,172 & 44,011 & 1,529 & 34,504 & 1,237 & 23,142 & 862 & 19,123 & 814 \\
\hline Less than 10 & 8,074 & 271 & 1,713 & 61 & 909 & 19 & 760 & 22 & 764 & 34 \\
\hline From 10 to 49 & 20,036 & 606 & 11,373 & 387 & 8,188 & 300 & 3,808 & 155 & 3,141 & 115 \\
\hline From 50 to 69 & 8,130 & 231 & 5,238 & 155 & 4,073 & 137 & 2,226 & 64 & & \\
\hline From 70 to 99 & 8,681 & 256 & 6,227 & 196 & 4,790 & 144 & 3,002 & 78 & 9,001 & 354 \\
\hline From 100 to 139 & 8,486 & 246 & 6,345 & 202 & 5,056 & 139 & 3,509 & 134 & & \\
\hline From 140 to 179 & 4,750 & 149 & 3,847 & 135 & 3,155 & 119 & 2,483 & 78 & & \\
\hline From 180 to 219 & 3,114 & 92 & 2,517 & 76 & 2,131 & 74 & 1,673 & 56 & 4,877 & 231 \\
\hline From 220 to 259 & 1,799 & 65 & 1,658 & 55 & 1,397 & 69 & 1,227 & 42 & & \\
\hline From 260 to 499 & 3,811 & 169 & 3,475 & 169 & 3,215 & 136 & 2,867 & 124 & & \\
\hline From 500 to 999 & 1,308 & 68 & 1,236 & 76 & 1,180 & 78 & 1,203 & 84 & 980 & 59 \\
\hline 1,000 and up & 394 & 19 & 382 & 17 & 410 & 22 & 384 & 25 & 270 & 21 \\
\hline
\end{tabular}


Table 4

Selected Land Transfers in Greenbrier County - 1970-1975

\begin{tabular}{|c|c|c|c|c|c|c|}
\hline Variable & $\begin{array}{l}\text { Number of } \\
\text { Transfers }\end{array}$ & Total & Average & Min & Max & $\begin{array}{l}\text { Standard } \\
\text { Deviation }\end{array}$ \\
\hline Area (acres) & 718 & 75,393 & 105 & 10. & 5,473 & 260.85 \\
\hline $\begin{array}{l}\text { Consideration } \\
\text { (dollars) }\end{array}$ & 718 & $14,384,835$ & 20,035 & 100. & 684,126 & $38,852.09$ \\
\hline $\begin{array}{l}\text { Per acre price } \\
\text { (dollars) }\end{array}$ & 718 & - & 190.80 & 2.48 & 7,060 & - \\
\hline
\end{tabular}




\section{Table 5}

Selected Land Transfers and Values

in Greenbrier County by Year — 1970-1975

\begin{tabular}{|c|c|c|c|c|c|c|c|}
\hline \multirow{2}{*}{$\begin{array}{l}\text { Year } \\
1970\end{array}$} & \multirow{2}{*}{$\begin{array}{c}\text { Transfers } \\
60\end{array}$} & \multirow{2}{*}{\multicolumn{2}{|c|}{$\begin{array}{lr}\text { Total } & \begin{array}{c}\text { Acreage } \\
\text { Average }\end{array} \\
6,282 & 104.70\end{array}$}} & \multicolumn{2}{|c|}{$\begin{array}{l}\text { Consideration } \\
\text { Total Average } \\
\text { (Dollars) }\end{array}$} & \multirow{2}{*}{$\begin{array}{c}\begin{array}{c}\text { Per } \\
\text { Acre } \\
\text { Price (\$) }\end{array} \\
112.40\end{array}$} & \multirow{2}{*}{$\begin{array}{r}\text { Index } \\
(1970= \\
100) \\
100.00\end{array}$} \\
\hline & & & & 706,072 & $11,767.87$ & & \\
\hline 1971 & 133 & 15,284 & 114.92 & $1,686,609$ & $12,681.27$ & 110.35 & 98.18 \\
\hline 1972 & 159 & 16,971 & 106.74 & $2,512,663$ & $15,802.91$ & 148.06 & 131.73 \\
\hline 1973 & 146 & 13,777 & 94.36 & $2,781,982$ & $19,054.69$ & 201.93 & 179.65 \\
\hline 1974 & 120 & 15,373 & 128.11 & $3,597,865$ & $29,982.21$ & 234.04 & 208.22 \\
\hline 1975 & 100 & 7,706 & 77.06 & $3,099,644$ & $30,996.44$ & 402.24 & 357.86 \\
\hline Total & 718 & 75,393 & 105.00 & $14,384,835$ & $20,035.00$ & 190.80 & - \\
\hline
\end{tabular}


Table 6

Average Per Acre Prices for Selected Land Transfers

in Greenbrier County by Years - 1970-1975,

in Constant 1972 Dollars

\begin{tabular}{|c|c|c|c|c|}
\hline Year & $\begin{array}{l}\text { Per Acre } \\
\text { Price } \\
\text { (Dollars) } \\
\text { (a) }\end{array}$ & $\begin{array}{l}\text { G.N.P. } \\
\text { Deflator } \\
\text { (Index)* } \\
\text { (b) }\end{array}$ & $\begin{array}{c}\text { Per Acre Price } \\
\text { in Constant } 1972 \\
\text { Dollars: }(a / b) 100\end{array}$ & $\begin{array}{c}\text { Deflated } \\
\text { Price Index } \\
(1970=100)\end{array}$ \\
\hline 1970 & 112.40 & 91.36 & 123.03 & 100.00 \\
\hline 1971 & 110.35 & 96.02 & 114.92 & 93.41 \\
\hline 1972 & 148.06 & 100.00 & 148.06 & 120.34 \\
\hline 1973 & 201.93 & 105.92 & 190.64 & 154.34 \\
\hline 1974 & 234.04 & 116.20 & 201.41 & 163.71 \\
\hline 1975 & 402.24 & 126.37 & 318.30 & 258.72 \\
\hline
\end{tabular}

*Source: Survey of Current Business 


\section{Table 7}

Selected Land Transfers and Values in Greenbrier County by Per Acre Price - 1970-1975

\begin{tabular}{|c|c|c|c|c|c|c|}
\hline \multirow{2}{*}{$\begin{array}{l}\text { Range of Per } \\
\text { Acre Price } \\
\text { (Dollars) } \\
\text { Less than } 100\end{array}$} & \multirow{2}{*}{$\begin{array}{c}\begin{array}{c}\text { Number of } \\
\text { Transfers }\end{array} \\
243\end{array}$} & \multirow{2}{*}{$\begin{array}{l}\text { Total }^{\text {A }} \\
31,178\end{array}$} & $\begin{array}{l}\text { Acreage } \\
\text { Average }\end{array}$ & \multicolumn{2}{|c|}{$\begin{array}{c}\text { Consideration } \\
\text { Total Average } \\
\text { (Dollars) }\end{array}$} & \multirow{2}{*}{$\begin{array}{r}\begin{array}{c}\text { Per Acre } \\
\text { Price } \\
\text { (Dollars) }\end{array} \\
53.64\end{array}$} \\
\hline & & & 128.30 & $1,672,338$ & $6,882.05$ & \\
\hline $100-499.99$ & 370 & 39,858 & 107.72 & $7,672,263$ & $20,792.60$ & 193.02 \\
\hline 500-999.99 & 56 & 2,164 & 38.64 & $1,471,500$ & $26,276.79$ & 679.99 \\
\hline $1,000-1,999.99$ & 36 & 1,812 & 50.33 & $2,332,963$ & $64,804.53$ & $1,287.51$ \\
\hline 2,000-2,999.99 & 6 & 230 & 38.33 & 567,790 & $94,631.67$ & $2,468.65$ \\
\hline $3,000-3,999.99$ & 3 & 72 & 24.00 & 236,000 & $78,666.67$ & $3,277.78$ \\
\hline $4,000-4,999.99$ & 1 & 25 & 25.00 & 100,260 & $100,260.00$ & $4,010.40$ \\
\hline $5,000-5,999.99$ & 2 & 43 & 21.50 & 233,061 & $116,530.50$ & $5,420.02$ \\
\hline $6,000-6,999.99$ & 0 & 0 & 0 & 0 & 0 & 0 \\
\hline 7,000 or more & 1 & 11 & 11.00 & 77,660 & $77,660.00$ & $7,060.00$ \\
\hline All transfers & 718 & 75,393 & 105.00 & $14,384,835$ & $20,035.00$ & 190.80 \\
\hline
\end{tabular}


Table 8

Selected Land Transfers and Values for Greenbrier County by Acreage — 1970-1975

\begin{tabular}{rrrrrrr}
\hline \multicolumn{1}{l}{$\begin{array}{l}\text { Acreage } \\
\text { Range }\end{array}$} & $\begin{array}{c}\text { Number of } \\
\text { Transfers }\end{array}$ & \multicolumn{2}{c}{$\begin{array}{c}\text { Total } \\
\text { Acreage }\end{array}$} & $\begin{array}{c}\text { Consideration } \\
\text { Average }\end{array}$ & \multicolumn{1}{c}{$\begin{array}{c}\text { Average } \\
\text { (Dollars) }\end{array}$} & $\begin{array}{c}\text { Per Acre } \\
\text { Price } \\
\text { (Dollars) }\end{array}$ \\
\hline & & & & & & \\
$10-24.9$ & 164 & 2,659 & 16.21 & $1,439,262$ & $8,775.99$ & 541.28 \\
$25-49.9$ & 170 & 6,107 & 35.92 & $1,915,896$ & $11,269.98$ & 313.72 \\
$50-74.9$ & 109 & 6,656 & 61.06 & $1,808,978$ & $16,596.13$ & 271.78 \\
$75-99.9$ & 66 & 5,666 & 85.85 & $1,068,278$ & $16,186.03$ & 188.54 \\
$100-149.9$ & 99 & 11,634 & 117.30 & $2,271,433$ & $22,943.77$ & 195.24 \\
$150-199.9$ & 37 & 6,375 & 172.30 & $1,522,696$ & $41,153.95$ & 238.85 \\
$200-299.9$ & 35 & 8,718 & 249.09 & $1,683,300$ & $48,094.29$ & 193.08 \\
$300-399.9$ & 17 & 5,699 & 335.24 & 675,549 & $39,738.18$ & 118.54 \\
$400-499.9$ & 7 & 2,966 & 423.71 & 330,000 & $47,142.86$ & 111.26 \\
$500-599.9$ & 7 & 4,247 & 606.71 & 370,850 & $52,978.57$ & 87.32 \\
$750-999.9$ & 2 & 1,914 & 957.00 & 241,187 & $120,593.50$ & 126.01 \\
1,000 and up & 5 & 12,752 & $2,500.40$ & $1,057,406$ & $211,481.20$ & 82.92 \\
Total & 718 & 75,393 & 105.00 & $14,384,835$ & $20,034.59$ & 190.80 \\
\hline
\end{tabular}


Table 9

Selected Land Transfers in Greenbrier County

by Rights Transferred - 1970-1975

\begin{tabular}{|c|c|c|c|c|c|c|}
\hline \multirow{3}{*}{$\begin{array}{c}\begin{array}{c}\text { Rights } \\
\text { Transferred }\end{array} \\
\text { Fee Simple }\end{array}$} & \multirow{3}{*}{$\begin{array}{r}\begin{array}{c}\text { Number of } \\
\text { Transfers }\end{array} \\
670\end{array}$} & \multirow{2}{*}{\multicolumn{2}{|c|}{ Acreage }} & \multicolumn{2}{|c|}{ Consideration } & \multirow{2}{*}{$\begin{array}{c}\text { Per Acre } \\
\text { Price } \\
\text { (Dollars) }\end{array}$} \\
\hline & & & & Total & $\begin{array}{l}\text { Average } \\
\text { rs) }\end{array}$ & \\
\hline & & 66,354 & 99.04 & $13,604,972$ & $20,305.93$ & 205.04 \\
\hline Surface only & 46 & 8,970 & 195.00 & 883,309 & $16,813.00$ & 98.47 \\
\hline Not known & 2 & 69 & 34.50 & 6,365 & $3,232.50$ & 93.70 \\
\hline Total & 718 & 75,393 & 105.00 & $14,384,835$ & $20,035.00$ & 190.80 \\
\hline
\end{tabular}




\section{CHARACTERISTICS OF THE LAND MARKET}

This section deals with information gathered from the sample of sellers and buyers of rural land in Greenbrier County from 1970 to 1975. It contains the personal characteristics of sellers and buyers of land, their motives for selling and buying these properties, the characteristics of the properties and certain legal and financial aspects of the transfers, as stated by both sellers and buyers of those lands.

\section{Buyers and Sellers of Land}

The general characteristics found of sellers and buyers of farmland are shown in Table 10. Sellers of land were generally older than buyers and had slightly higher average incomes. However, the high values of the standard deviations of the incomes indicate large variations in incomes of both buyers and sellers.

The average buyer of rural land had more years of education than the average seller. Since the sellers were older this could be expected as education levels have increased steadily. The typical buyer appears to have completed high school, whereas the typical seller had only nine years education.

The main sources of income for sellers and buyers of rural land are presented in Table 11. The most important source of income for sellers was farming, while more buyers earned their incomes as laborers. Another important source of income for both sellers and buyers of rural land was from sales or clerical jobs. The number of buyers who were professionals was greater than the number of sellers. This might indicate a tendency for affluent people to move to rural areas to live or for retirement and for vacation purposes or that buying land for investment also is present.

As a consequence of land transfers that were made between 1970 and 1975 in Greenbrier County, some changes occurred in the working status of both sellers and buyers of these properties. The last two columns of Table 11 indicate that 13 of 43 farmers who sold land left farming as their main activity, while five buyers became farmers after purchasing the land, a net reduction of eight in the number of farmers. The net number of laborers decreased by eight. Four people who sold land and were in sales or clerical jobs left that activity after the transfer was made, while one person who bought rural land entered into this category after the purchase. The number of professionals also decreased by five and the category "others" lost four. Finally, the number of retirees, most of whom were sellers, increased by 28 . This last item indicates that transfers of land and retirement are related in this area but that probably relatively little rural land is being bought for retirement homes, at least at the time of retirement.

\section{Reasons for Selling and Buying Rural Land}

Sellers and buyers of land in the sample were asked to state their main reasons for selling and buying those properties. The seller's responses are listed in Table 12. Among sellers, 33 percent sold their properties because they needed the money, 31 percent said that they were too old for taking proper care of the land, 18 percent sold their land because they believed the price was right, and 12 percent disposed of their farms because they considered farming was no longer a good business. The most common complaint heard in this regard was that at today's prices farmers can barely 
make it. Finally, 11 percent stated other reasons for selling their land, among which inheritance was a common reason.

Table 13 shows the reasons for buying land. Nineteen percent of the buyers purchased land as an investment, of whom 4 percent were farmers, 5 percent laborers, 2 percent administrators, 13 percent sales or clerical people, 4 percent professionals, and 2 percent were retirees. Nineteen percent gave part-time farming as their main reason for buying the properties. These buyers were composed of 2 percent farmers, 11 percent laborers, 2 percent sales or clerical workers, 3 percent professionals, and 1 percent retirees. Another 19 percent of the buyers said they bought the rural properties for reasons not listed in the questionnaire, the most important of which was that they needed the land to build homes. This 19 percent was made up of 8 percent laborers, 4 percent sales or clerical related employees, 2 percent professionals, 2 percent retirees and 3 percent others (bond-holders mainly). Six percent bought land for second homes and the other 24 percent for farming full time, to begin farming, or to expand farming operations. Nearly all of these latter groups were farmers both before and after the sale. Thus, counting the pruchases for part-time farming, about 43 percent of the purchases of rural land were for agricultural uses.

Table 10

Personal Characteristics of Sellers and Buyers of Rural Land in Greenbrier County, West Virginia - 1970-1975

Characteristic

\begin{tabular}{llrr}
\hline Age (years) & Sellers & 63 & 11 \\
& Buyers & 42 & 11 \\
& & & 3 \\
Education (years) & Sellers & 9 & 4 \\
& Buyers & 12 & \\
Yearly income (dollars) & Sellers & 15,147 & 31,669 \\
& Buyers & 14,534 & 15,228
\end{tabular}


Table 11

Source of Income of Sellers and Buyers of Rural Land

in Greenbrier County, West Virginia — 1970-1975

\begin{tabular}{|c|c|c|c|c|c|}
\hline \multirow[b]{2}{*}{ Source } & \multicolumn{3}{|c|}{ Numbers } & \multicolumn{2}{|r|}{ Change } \\
\hline & & Before the Sale & After the Sale & No. & Net* \\
\hline No Answer & $\begin{array}{l}\text { Seller } \\
\text { Buyer }\end{array}$ & - & $\overline{1}$ & $\begin{array}{l}+1 \\
+1\end{array}$ & +1 \\
\hline Farmer & $\begin{array}{l}\text { Seller } \\
\text { Buyer }\end{array}$ & $\begin{array}{l}43 \\
15\end{array}$ & $\begin{array}{l}30 \\
20\end{array}$ & $\begin{array}{l}-13 \\
+5\end{array}$ & -8 \\
\hline Laborer & $\begin{array}{l}\text { Seller } \\
\text { Buyer }\end{array}$ & $\begin{array}{l}17 \\
17\end{array}$ & $\begin{array}{l}14 \\
13\end{array}$ & $\begin{array}{l}-3 \\
-4\end{array}$ & -7 \\
\hline Administrative & $\begin{array}{l}\text { Seller } \\
\text { Buyer }\end{array}$ & $\begin{array}{l}7 \\
4\end{array}$ & $\begin{array}{l}5 \\
3\end{array}$ & $\begin{array}{l}-2 \\
-1\end{array}$ & -3 \\
\hline $\begin{array}{l}\text { Sales or } \\
\text { Clerical }\end{array}$ & $\begin{array}{l}\text { Seller } \\
\text { Buyer }\end{array}$ & $\begin{array}{l}13 \\
20\end{array}$ & $\begin{array}{l}10 \\
21\end{array}$ & $\begin{array}{r}-3 \\
+1\end{array}$ & -2 \\
\hline Professional & $\begin{array}{l}\text { Seller } \\
\text { Buyer }\end{array}$ & $\begin{array}{r}4 \\
17\end{array}$ & $\begin{array}{r}2 \\
14\end{array}$ & $\begin{array}{l}-2 \\
-3\end{array}$ & -5 \\
\hline Retired & $\begin{array}{l}\text { Seller } \\
\text { Buyer }\end{array}$ & $\begin{array}{r}13 \\
4\end{array}$ & $\begin{array}{r}39 \\
6\end{array}$ & $\begin{array}{r}+26 \\
+2\end{array}$ & +28 \\
\hline Other & $\begin{array}{l}\text { Seller } \\
\text { Buyer }\end{array}$ & $\begin{array}{l}5 \\
5\end{array}$ & $\begin{array}{l}2 \\
4\end{array}$ & $\begin{array}{l}-3 \\
-1\end{array}$ & -4 \\
\hline
\end{tabular}

${ }^{*}$ Net change incluces both buyers and sellers 
Table 12

Seller's Main Reasons for Selling the Land

in Greenbrier County, West Virginia - 1970-1975

\begin{tabular}{lcc} 
Reasons & Number & Total \\
\hline Needed the money & 42 & 33 \\
Right price to sell & 23 & 18 \\
Farming not good business & 12 & 9 \\
Age & 39 & 31 \\
Other reasons & 11 & 9 \\
Total & 127 & 100
\end{tabular}

\section{Consideration and Acreage}

For the 102 transfers included in the sample there was a total value of $\$ 2,573,040$ and an average of $\$ 25,252.88$ per parcel (Table 14). The total acreage was 6,590 or 64.6 acres per parcel and the average price per acre was $\$ 390.45$. Sellers of the sample properties were asked to estimate the value of livestock, equipment, buildings, and bare land as components of the consideration (lower section of Table 14). Livestock was part of the sale of land in four transfers, equipment was sold in five transfers, and 61 of the transferred properties had buildings on them. When the values of these items were added, a discrepancy of $\$ 51,675$ with total consideration was found. This was because total consideration was taken from court house records, while the estimations by components were made by the sellers.

\section{Land Use at Time of Sale}

Table 15 shows that on the average about 12 percent of the land trans. ferred was being used as cropland at the time of the sale. About 41 percent was used for pastureland and 27 percent for woodland. These results generally agree with the census data on land use in Greenbrier County. The item "other surface" refers to buildings, water surface, road surface, waste land, and idle land. All other uses together represented about 20 percent of the land area transferred.

\section{Financing of Land Purchases}

Table 16 shows how land purchases were financed in Greenbrier County during the 1970-1975 period. Buyers of farms used about 45 percent of their own funds to purchase these properties and borrowed the remaining 55 percent. Of the borrowed funds, about 38 percent was provided by financial in. 
stitutions, 7 percent came from individuals, 6 percent was deferred payments granted by the sellers of those land, and 4 percent came from other sources.

In particular, it was found that of 102 transfers of land, five buyers purchased land using their own money exclusively. The financial institutions aided in 72 transfers, the sellers provided credit for 10 transfers, 9 purchases were made utilizing individual credits, and 6 transfers used other financial sources. Most were financed by use of a mortgage but several (19) were financed under sales contracts while a few were financed only through a promisory note or other security.

The financial institutions which have been referred to were commercial banks, the Federal Land Bank, the Farmer's Home Administration, Insurance Companies, and other financial institutions. The FHA and the FLB charged lower annual interest rates for their loans (6.05 and 6.88 percent respectively, as informed by the buyers) followed by insurance companies which charged 7.0 percent, banks with 7.84 percent, and credit sources labelled "other institutions" 9.0 percent.

\section{THE REGRESSION MODEL}

The analysis was based on the hypothesis that the factors affecting land values of rural land is a function of several variables. These were organized into three groups: 1) independent variables describing the characteristics of the property, 2) variables showing the socioeconomic characteristics of sellers or buyers of those properties, and 3) variables related to the transfer itself. Two models were used, one specifically for the sellers of the rural properties in the county and the other for the buyers of the same properties. ${ }^{*}$ These were estimated by use of multiple linear regression as represented by two equations:

1. $E\left(Y_{s}\right)=A_{s}+B_{i l s} X_{i l s}+B_{i 2 s} X_{i 2 s}+B_{i 3 s} X_{i 3 s}$

2. $E\left(Y_{b}\right)=A_{b}+B_{i l b} X_{i l b}+B_{i 2 b} X_{i 2 b}+B_{i 3 b} X_{i 3 b}$

Where: $E\left(Y_{s}\right)=E\left(Y_{b}\right)$ and:

$Y=$ deflated per acre price of the properties transferred

$X_{i}=$ the dependent variables

$B_{i}=$ the partial regression coefficients, and

$s=$ seller's information

$\mathrm{b}=$ buyer's information

"The seller's and buyer's models represent supply and demand models only in a loose sense. Since quantities are not represented except as parcel size the usual price-quantity relationship is not included in this model. 


\section{Table 13}

Types of Buyers and Their Reasons for Buying Rural Land in Greenbrier County

\begin{tabular}{|c|c|c|c|}
\hline $\begin{array}{c}\text { Type of } \\
\text { of } \\
\text { Buyer }\end{array}$ & & $\begin{array}{c}\text { Full. } \\
\text { Time } \\
\text { Farming }\end{array}$ & $\begin{array}{l}\text { Part } \\
\text { Time } \\
\text { Farmin }\end{array}$ \\
\hline \multirow[t]{4}{*}{ Farmer } & Number & 6 & \\
\hline & Percent of total & 6.12 & $2 k$ \\
\hline & Row percent & 35.29 & $11 . \pi$ \\
\hline & Column percent & 85.17 & 10.5 \\
\hline \multirow[t]{4}{*}{ Laborer } & Number & 0 & " \\
\hline & Percent of total & 0.00 & 11.2 \\
\hline & Row percent & 0.00 & 33.3 \\
\hline & Column percent & 0.00 & 57. \\
\hline \multirow[t]{4}{*}{ Administrative } & Number & 0 & \\
\hline & Percent of total & 0.00 & 0.00 \\
\hline & Row percent & 0.00 & 0.00 \\
\hline & Column percent & 0.00 & 0.00 \\
\hline \multirow[t]{4}{*}{ Sales or Clerical } & Number & 0 & ? \\
\hline & Percent of total & 0.00 & 2.04 \\
\hline & Row percent & 0.00 & 9.52 \\
\hline & Column percent & 0.00 & 10.53 \\
\hline \multirow[t]{4}{*}{ Professional } & Number & 0 & \\
\hline & Percent of total & 0.00 & 3.06 \\
\hline & Row percent & 0.00 & 21.43 \\
\hline & Column percent & 0.00 & 15.79 \\
\hline \multirow[t]{4}{*}{ Retired } & Number & 0 & \\
\hline & Percent of total & 0.00 & 1.02 \\
\hline & Row percent & 0.00 & 16.67 \\
\hline & Column percent & 0.00 & \\
\hline \multirow[t]{4}{*}{ Other } & Number & 1 & \\
\hline & Percent of total & 1.02 & 0.00 \\
\hline & Row percent & 25.00 & 0.00 \\
\hline & Column percent & 14.29 & 0.00 \\
\hline \multirow[t]{2}{*}{ Total } & Number & 7 & 19 \\
\hline & Percent & 7.14 & 9.39 \\
\hline
\end{tabular}




\begin{tabular}{|c|c|c|c|c|c|}
\hline $\begin{array}{l}\text { Segin } \\
\text { Iming }\end{array}$ & $\begin{array}{c}\text { For } \\
\text { Expansion } \\
\text { of Farming }\end{array}$ & $\begin{array}{c}\text { Reasons } \\
\text { For } \\
\text { Second } \\
\text { Home }\end{array}$ & $\begin{array}{l}\text { Buying } \\
\text { As an } \\
\text { Invest- } \\
\text { ment }\end{array}$ & $\begin{array}{c}\text { Other } \\
\text { Reasons }\end{array}$ & Total \\
\hline $\begin{array}{l}0 \\
1.00 \\
100 \\
100\end{array}$ & $\begin{array}{r}5 \\
5.10 \\
29.41 \\
62.50\end{array}$ & $\begin{array}{r}0 \\
0.00 \\
0.00 \\
0.00\end{array}$ & $\begin{array}{r}4 \\
4.08 \\
23.53 \\
13.33\end{array}$ & $\begin{array}{r}0 \\
0.00 \\
0.00 \\
0.00\end{array}$ & $\begin{array}{r}17 \\
17.35\end{array}$ \\
\hline $\begin{array}{r}5 \\
\$ 10 \\
215 \\
356\end{array}$ & $\begin{array}{r}2 \\
2.04 \\
6.06 \\
25.00\end{array}$ & $\begin{array}{r}2 \\
2.04 \\
6.06 \\
33.33\end{array}$ & $\begin{array}{r}5 \\
5.10 \\
15.15 \\
16.67\end{array}$ & $\begin{array}{r}8 \\
8.16 \\
24.24 \\
42.11\end{array}$ & $\begin{array}{r}33 \\
33.67\end{array}$ \\
\hline $\begin{array}{r}1 \\
1.02 \\
1.33 \\
1.11\end{array}$ & $\begin{array}{r}0 \\
0.00 \\
0.00 \\
0.00\end{array}$ & $\begin{array}{r}0 \\
0.00 \\
0.00 \\
0.00\end{array}$ & $\begin{array}{r}2 \\
2.04 \\
66.67 \\
6.67\end{array}$ & $\begin{array}{r}0 \\
0.00 \\
0.00 \\
0.00\end{array}$ & $\begin{array}{r}3 \\
3.06\end{array}$ \\
\hline $\begin{array}{r}0 \\
0.00 \\
0.00 \\
0.00\end{array}$ & $\begin{array}{r}0 \\
0.00 \\
0.00 \\
0.00\end{array}$ & $\begin{array}{r}2 \\
2.04 \\
66.67 \\
6.67\end{array}$ & $\begin{array}{r}13 \\
13.27 \\
61.90 \\
43.33\end{array}$ & $\begin{array}{r}4 \\
4.08 \\
19.05 \\
21.05\end{array}$ & $\begin{array}{r}21 \\
21.43\end{array}$ \\
\hline $\begin{array}{r}2 \\
2.04 \\
4.29 \\
2.22\end{array}$ & $\begin{array}{r}1 \\
1.02 \\
7.14 \\
12.50\end{array}$ & $\begin{array}{r}2 \\
2.04 \\
14.29 \\
33.33\end{array}$ & $\begin{array}{r}4 \\
4.08 \\
28.57 \\
13.33\end{array}$ & $\begin{array}{r}2 \\
2.04 \\
14.29 \\
21.05\end{array}$ & $\begin{array}{r}14 \\
14.29\end{array}$ \\
\hline $\begin{array}{r}1 \\
1.02 \\
6.67 \\
5.26\end{array}$ & $\begin{array}{r}0 \\
0.00 \\
0.00 \\
0.00\end{array}$ & $\begin{array}{r}0 \\
0.00 \\
0.00 \\
0.00\end{array}$ & $\begin{array}{r}2 \\
2.04 \\
33.33 \\
10.53\end{array}$ & $\begin{array}{r}2 \\
2.04 \\
33.33 \\
10.53\end{array}$ & $\begin{array}{r}6 \\
6.12\end{array}$ \\
\hline $\begin{array}{r}0 \\
0.00 \\
0.00 \\
0.00\end{array}$ & $\begin{array}{r}0 \\
0.00 \\
0.00 \\
0.00\end{array}$ & $\begin{array}{r}0 \\
0.00 \\
0.00 \\
0.00\end{array}$ & $\begin{array}{r}0 \\
0.00 \\
0.00 \\
0.00\end{array}$ & $\begin{array}{r}3 \\
3.06 \\
75.00 \\
15.79\end{array}$ & $\begin{array}{r}4 \\
4.08\end{array}$ \\
\hline $\begin{array}{r}9 \\
9.18\end{array}$ & $\begin{array}{r}8 \\
8.16\end{array}$ & $\begin{array}{r}6 \\
6.12\end{array}$ & $\begin{array}{r}19 \\
19.39\end{array}$ & $\begin{array}{r}19 \\
1 \mathrm{t} .39\end{array}$ & $\begin{array}{r}98 \\
100.00\end{array}$ \\
\hline
\end{tabular}


Table 14

Consideration and Acreage for the Sample of Rural Land Sales in Greenbrier County, West Virginia - 1970-1975

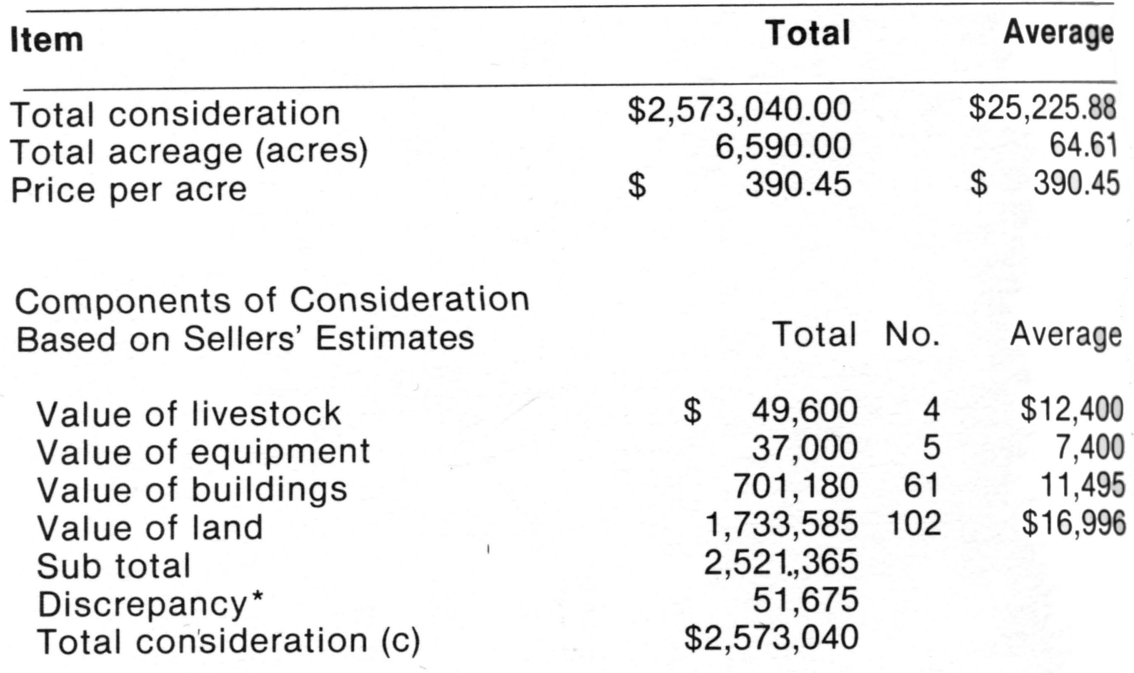

\section{Table 15}

Land Use on an Average Farm at the Time of Sale

\begin{tabular}{lrcrr} 
Use & $\begin{array}{r}\text { Total } \\
\text { Acreage }\end{array}$ & $\begin{array}{c}\text { Standard } \\
\text { Deviation }\end{array}$ & Percent & $\begin{array}{r}\text { Average } \\
\text { Acreage }\end{array}$ \\
\hline Cropland & 761 & 15 & 11.55 & 7.46 \\
Pastureland & 2,696 & 40 & 40.91 & 26.43 \\
Woodland & 1,800 & 27 & 27.31 & 17.65 \\
Other surface & 1,333 & 34 & 20.23 & 13.07 \\
Total & 6,590 & - & 100.00 & 64.61
\end{tabular}

*Difference between total value of all sales from courthouse records and the compo. nent estimates made by sellers. 
Table 16

\section{Financing of Land Purchases in Greenbrier County, West Virginia - 1970-1975}

Financial Source

Buyer's own money

Financial institution loan

Individual credit

Seller's credit

5.88

Other sources

Total
Average Percent of the Purchase Price

\section{The Sellers' Model}

Among the group of variables related to property characteristics hypothesized to have a relationship to the price sellers would take for their properties, there was a subgroup of continuous variables: acreage of the property, total value of the property, per acre value of improvements and present use, measured as acres of cropland, pastureland, woodland and other land (idle, service and wasteland). The second subgroup consisted of classification variables: type of water supply for the farm and rights sold which were classified as fee simple or surface only.

In the socioeconomic group of independent variables, there also were some continuous and some classification variables. The continuous variables were age and education of the sellers measured in number of years and income measured in dollars per year. The classification variables were seller's place of residence, "living on the property" or "absent," and seller's occupation before and after the sale.

The transaction variables thought to be related to the price were percent of the sale price of the property financed by the seller and number of years of deferred payment, while the classification variables were the sellers' stated reasons for selling the land.

\section{The Buyers' Model}

This model also had three groups of independent variables. In the first group, which were those that describe the characteristics of the property, there were two subgroups. It was composed of the following continuous variables: total acreage of the property, total value of the property, per acre value of the improvements, location measured as total mileage to the nearest town, present use of acres of cropland, pastureland, woodland and other land, and best use expressed as acres of tillable land, acres of 
pastureland, acres of woodland, and acres of wasteland. Among the classification variables were type of water supply, and type of rights ac. quired which were classified as fee simple rights or surface rights only.

Among the second group of variables continuous independent variables hypothesized to be related to the price of land were the ages and education of the buyers of rural land measured in number of years and incomes of buyers in dollars per year. The classification variables were occupation of the buyers before and after the purchase of these properties and their place of residence after the purchase. This latter was to detect absenteeism and its relation to the purchase price.

The third group of independent variables describe the characteristics of the transfers themselves and included the following continuous variables: percentage of the sale price financed by the buyer's own money, percent of the sale price financed with credit, and rate of interest of the loan. The classification variable of this group described the subjective type of reasons of buyers for buying these properties.

\section{Regression Results}

Data from the 102 transfers for both the sellers and buyers of rural land in Greenbrier County, West Virginia, along with the complementary data from courthouse records were organized according to the working hypotheses about the factors affecting rural land values. Multiple linear regression was used to estimate the parameters of the models in equations 1 and 2.

\section{Sellers' Model}

The results for the sellers' model are given in Table 17 although coefficients for only nine statistically significant variables are included. The dependent variable was the average deflated per acre value of land in the 1970-1975 period. The overall average price for this period was $\$ 390.45$ per acre and the corresponding deflated value was $\$ 359.46$. The $R$ square value, the coefficient of determination, was .72, indicating that 72 percent of the variability in per acre price is explained by the independent variables. The $F$ ratio was statistically highly significant indicating that the variability of per acre prices is not apt to be due solely to chance. Although only 11 of the 45 variables were statistically significant (at the 0.05 level) only six of the 45 regression coefficients had signs different than hypothesized. *

The independent variable, total acreage of the property, had a negative relationship to per acre price equal to 3.06, which indicates that in average terms a variation of one acre in the size of a property sold in Greenbrier County will cause a $\$ 3.06$ inverse change in its per acre sale price. The deflated per acre value of buildings was positively related to the dependent variable per acre price. The regression coefficient of 1.029 indicates that an average property's per acre price will change by about $\$ 1.03$ for each dollar change in the per acre value of buildings. Income of sellers and per acre price also were directly related. The magnitude of this relationship is given by the $B$ value of 0.0080 which in average terms indicates that for every ad. ditional $\$ 1,000$ that a particular seller has there will be an extra charge of $\$ 8.00$ per acre on the sale price of the property.

*Although the model contained 45 variables, 31 of those were in five groups of classification variables. 
The classification variables, for which the B values were statistically significant were:

Rights Transferred in the Sale

Surface rights

Fee simple rights

Occupation of Sellers After the Sale

Farmer

Laborer

Retired

Reasons for Selling the Land

Needed the money

Right price to sell

Farming bad business

The partial regression coefficients of classification variables tell how much the presence of the variables will influence the per acre price, that is, they act as shifters of the intercept, A. Because of the nature of dummy variabies for classes with more than two values they have more meaning as a group in the predictive equation than as individual variables.

\section{Buyers' Model}

Multiple linear regression also was used to analyze the information gathered from buyers of rural properties. A summary of the analysis is given in Table 18. The highly statistically significant $F$ value shown in this table indicates that the variability of the dependent variable, deflated per acre price, is related to the independent variables. The $R$ square or coefficient of determination at 0.86 indicates that 86 percent of the total variability of per acre prices is explained by the contribution of all independent variables.

Table 18 also shows the estimated regression coefficients of the multiple regression equation and the tests for all variables which were statistically significant at the 0.05 level or better. As in the sellers' model there were 11 statistically significant coefficients, but many were for different variables. The first is the deflated per acre value of buildings which on the average and from the buyer's point of view tended to directly change per acre price by $\$ 0.907$ for each one dollar change in its value. The second is the rate of interest on credit obtained by buyers from insurance companies which had a large effect on the purchase price. It means on the average that a 1 percent increase in the interest rate is associated with a $\$ 163$ higher per acre price. However, very few buyers obtained credit from insurance companies. The other significantly related variables were all classification: nearest town is Frankford, reason for buying is "other," and the occupations of farmer, laborer, administrative work, sales or clerical, professional, retired and self employed or other. 
Table 17

Statistically Significant Partial

Regression Coefficients in the Sellers' Model

\begin{tabular}{lrrr}
\hline $\begin{array}{l}\text { Independent } \\
\text { Variables }\end{array}$ & B Values & $\begin{array}{r}\text { f for HO: } \\
\text { B }=0\end{array}$ & Prob t \\
\hline Size of parcel & -3.0622 & -2.98 & 0.0050 \\
Value of buildings per acre & 1.0292 & 3.04 & 0.0036 \\
Sold surface only & -922.9082 & -2.74 & 0.0082 \\
Sold in fee simple & 370.5386 & 1.92 & 0.0592 \\
Seller's income & 0.0080 & 2.51 & 0.0148 \\
Seller was farmer & 112.1729 & 4.14 & 0.0001 \\
Seller was laborer & 1048.2634 & 2.56 & 0.0133 \\
Seller was retiree & 929.1216 & 3.04 & 0.0036 \\
Seller needed money & -477.0650 & -2.95 & 0.0046 \\
Seller thought price was right & -494.0235 & -2.29 & 0.0261 \\
Seller thought farming was & & & \\
$\quad$ a bad business & -545.7802 & -2.40 & 0.0197 \\
\hline
\end{tabular}

$\mathrm{R}^{2}=.718 \mathrm{~F}$ Ratio $=2.925$ (Probability of $\mathrm{F}=0.0002$ ) 
Table 18

Statistically Significant Partial Regression

Coefficients in the Buyers' Model

\begin{tabular}{lrr}
\hline Variable & $\begin{array}{c}\text { Regression } \\
\text { Coefficient* }\end{array}$ & t-Value* \\
\hline Value of buildings per acre & 0.90731 & 2.663 \\
Interest rate of insurance cos. & 163.22888 & 2.174 \\
Nearest town in Frankford & 1186.45462 & 2.955 \\
Buyer's occupation is: & & \\
Farming & 2139.01178 & 3.574 \\
Laborer & 1686.88862 & 2.448 \\
Administration & 3076.78325 & 2.421 \\
Sales or Clerical & 2906.96436 & 3.419 \\
Professional & 2436.03934 & 2.698 \\
Retired & 2025.31471 & 2.313 \\
Self employed \& other & 3472.19802 & 2.620 \\
Buyer's reason for purchase is: & & \\
Other & 396.23205 & 1.989 \\
\hline
\end{tabular}

$\mathrm{R}^{2}=.86 \mathrm{~F}$ Ratio $=3.041$ (Probability of $\mathrm{F}=.0006$ ).

${ }^{*} \mathrm{t}=$ Regression Coef./Standard Error. 


\section{CONCLUSIONS}

Supply and demand basically determine land values, even though the nonstandardized nature of the real estate market's product introduces an almost endless number of individualizing qualities that make a particular piece of land a unique product in the market.

Information about the rural real estate market tends to be disseminated slowly when compared with other products, but when a transfer of land is in prospect the information needed to appraise the situation can be found, primarily in a network of knowledge by people and public records.

Since about 1963 land values in West Virginia and Greenbrier County have been increasing faster than in the rest of the United States. From 1970 to 1975 land values in Greenbrier County increased about 146 percent more than the general level of prices. This indicates the strength of the trend in land values in the region which rose from an average of $\$ 112.40$ per acre in 1970 to $\$ 402.24$ in 1975 . This trend appears likely to continue or even to ac. celerate due, in part, to the energy situation which may call for increased use of the nation's own energy resources of which coal will play a prominent role. It appears, from discussions with the buyers and sellers, that the transfer of rural land in Greenbrier County usually takes place between sellers and buyers directly. The role of real estate agents is small, their ser. vices seem more important in the urban and suburban land markets.

Individuals gave many reasons for selling and buying rural land in Green. brier County. The sellers were older, less educated, and had higher incomes than the buyers. Many were retiring and that was a prominent reason for selling land. Land was bought more often for either residential uses or for farming than for other reasons. Land was purchased by 42 percent of the buyers specifically for farming which included purchases of complete farms, land for farm expansion, and land for part-time farms. Some agricultural products, primarily beef cattle, were produced on 58 percent of the 102 rural properties in 1975.

Less than 5 percent of the purchasers used only their own funds and typically borrowed about 60 percent. Most of the borrowed funds came from financial institutions - banks, insurance companies, the Federal Land Bank, and Farmers Home Administration. The sellers, however, helped finance many of the land transfers, with land purchase contracts used fre. quently for the purpose. Interest rates varied from 4 to 12 percent with an average of about 6.8 percent.

Analysis of the information obtained from the sellers of rural land in Greenbrier County showed that a variation of one acre in the size of a pro. perty for sale in the county will tend to cause a $\$ 2.98$ inverse change in its per acre sale price, that an increase of one dollar in the per acre value of buildings will cause an increase of $\$ .90$ to $\$ 1.00$ in the per acre sale price of the property, and that for every additional $\$ 1,000$ yearly income that a particular seller has the per acre sale price of a property is likely to go up by $\$ 3.65$. This last relationship suggests that the relative financial stability and affluence of a landowner lets him obtain a higher price when he sells property.

It was found that seller's and buyer's evaluations of the same property are different. In general, buyers tended to over-value the improvements of the properties relative to the sellers' evaluations. Analysis of the informa- 


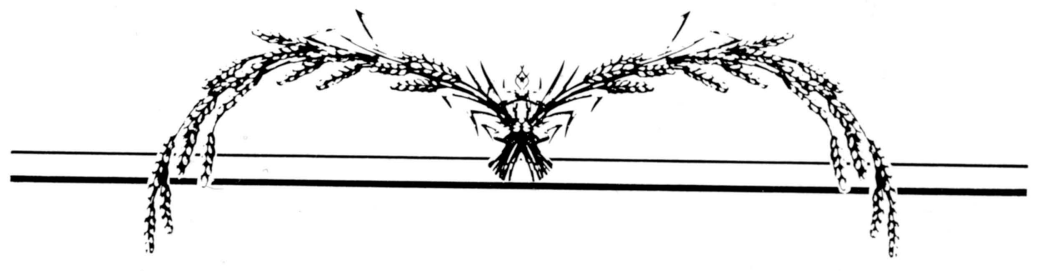

